\title{
Er svingende blodtrykk et faretegn?
}

\author{
Store variasjoner i blodtrykket er assosiert med økt risiko for hjerte- \\ og karsykdommer og økt dødelighet.
}

Gjennomsnittlig blodtrykk i løpet av en dag er gullstandarden for måling av blodtrykk og legger grunnlaget for behandlingsvalg. Høye enkeltmålinger blir sett bort ifra når gjennomsnittet er normalt.

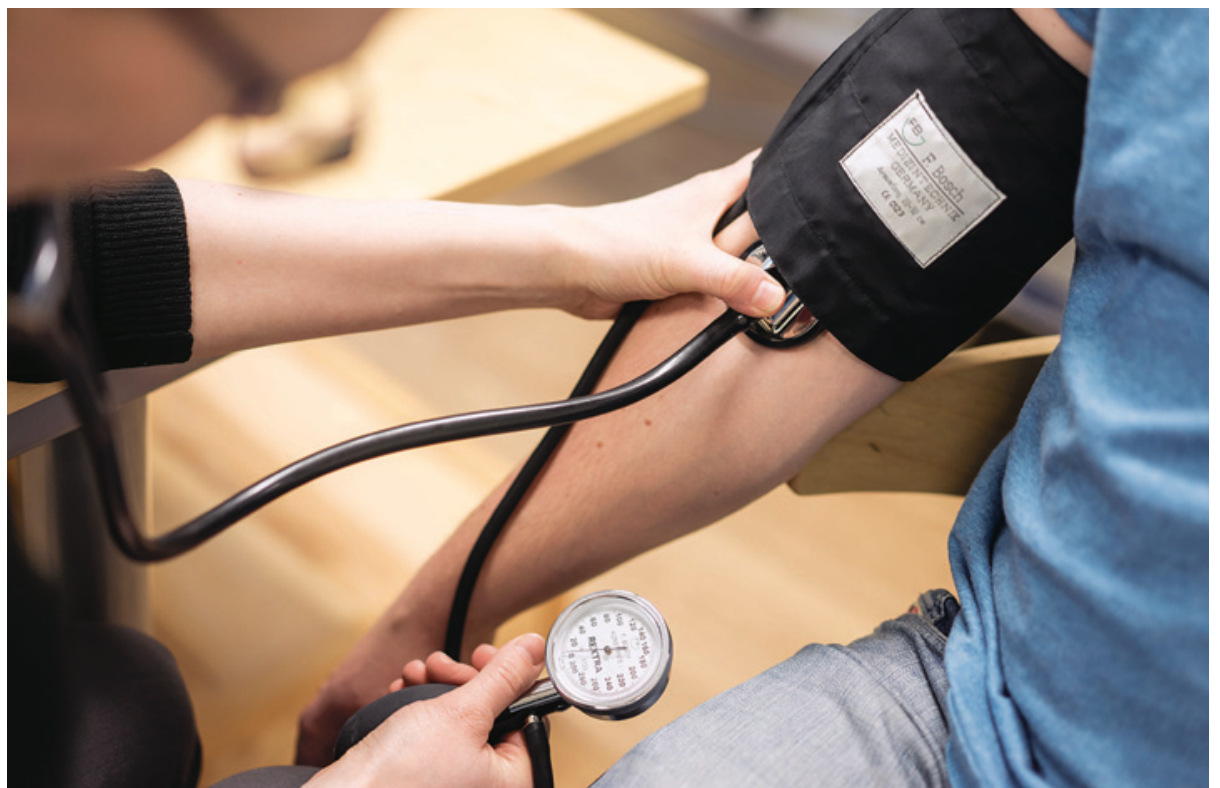

Illustrasjonsfoto: Ole Kristian Losvik
I en amerikansk studie fikk flere enn 25000 pasienter målt blodtrykket syv ganger over en toårsperiode (1). Dataene fra disse blodtrykksmålingene ble $\mathrm{i}$ ettertid tatt ut og brukt for å se om pasienter med store

svingninger i blodtrykket hadde økt risiko for hjerte- og karsykdommer og økt dødelighet. Pasienter med stor variasjon i gjennomsnittlig systolisk blodtrykk hadde 1,6 ganger øt total dødelighet, 1,5 ganger økt risiko for hjerneslag og 1,3 ganger økt risiko for iskemisk hjertesykdom enn dem med liten variasjon - alle funn med statistisk signifikans.

- Denne studien indikerer at det går dårligst med dem som har størst variabilitet i blodtrykk, spesielt med henblikk på hjerneslag og død, sier Jan Erik Nordrehaug, professor i kardiologi ved Universitetet i Bergen. - Det er også interessant at diuretikum som monoterapi gir høyere forekomst av hjerneslag, sier han.

- En styrke ved studien er at man har selektert pasienter som behandles i samsvar med norske retningslinjer, dvs. med diuretikum, kalsiumantagonist og/eller ACEhemmer. Resultatene skyldes neppe slurv med å ta medikamentene. En svakhet er at studien ikke er randomisert spesifikt med henblikk på blodtrykksvariabilitet. Studien kan derfor bare si noe om assosiasjoner og ikke om årsaksforhold, sier Nordrehaug.

\section{Kaveh Halland Rashidi}

Tidsskriftet

\section{Litteratur}

1. Muntner P, Whittle J, Lynch Al et al. Visit-to-visit variability of blood pressure and coronary heart disease, stroke, heart Failure, and mortality: a cohort study. Ann Intern Med 2015; 163: 329-38.

\section{Hvor intensiv bør blodtrykksbehandling være?}

\section{Intensiv blodtrykksbehandling gir lavere risiko for hjerte- og karsyk- dom og død enn standardbehand- ling, viser en ny studie.}

I den såkalte SPRINT-studien, som nylig er publisert i New England Journal of Medicine (1), ble flere enn 9300 pasienter med systolisk blodtrykk $>130 \mathrm{~mm} \mathrm{Hg}$ og økt risiko for hjerte- og karsykdom, men uten diabetes, randomisert til å få intensiv blodtrykksbehandling med målblodtrykk $<120$ mm Hg eller standardbehandling med målblodtrykk $<140 \mathrm{~mm} \mathrm{Hg}$.

Etter ett år var gjennomsnittsblodtrykk i intervensjonsgruppen $121,4 \mathrm{~mm} \mathrm{Hg}$ og $136,2 \mathrm{~mm} \mathrm{Hg}$ i kontrollgruppen. Studien ble avbrutt før planlagt, fordi det var signifikant lavere risiko for hjerte- og karsykdom og død $\mathrm{i}$ intervensjonsgruppen enn i kontrollgruppen (hasardratio 0,75 ; $95 \%$ KI $0,64-0,90$ ). Pasientene i intervensjonsgruppen hadde flest bivirkninger, bl.a. hypotensjon, synkope, elektrolyttforstyrrelser og nyresvikt, men ikke flere skader forårsaket av fall.

- Denne studien har vært omtalt som banebrytende av flere hypertensjonseksperter, sier Tonje Amb Aksnes, overlege og ph.d. ved Seksjon for invasiv kardiologi, Oslo universitetssykehus, Ullevål. - Men det har også kommet kritiske innvendinger. Hovedfunnet var reduksjon i hjertesvikt. Ettersom systolisk blodtrykk ved studiestart i snitt var relativt moderat, på $140 \mathrm{~mm} \mathrm{Hg}$, kan det være at de gode resultatene ved intensivbehandling beror på at kontrollgruppen fikk redusert sin blodtrykksbehandling, særlig med diuretika, sier hun.
- I alle studier blir pasientene fulgt tettere enn det som er mulig i normal klinisk praksis. I denne studien ble det brukt helautomatisk blodtrykksmåling etter fem minutters hvile $i$ et stille rom. Dette gjør at resultatene ikke nødvendigvis er overførbare til klinisk praksis. Denne studien vil bli mye diskutert, ettersom høyt blodtrykk er den viktigste risikofaktoren for kardiovaskulær sykdom og død, sier Aksnes.

\section{Martine Rostadmo}

Tidsskriftet

\section{Litteratur}

1. Wright JT Jr, Williamson JD, Whelton PK et al. A randomized trial of intensive versus standard blood-pressure control. N Engl J Med 2015; 373: 2103-16. 